7-31-2018

\title{
Folk categorizations of western Champa in Cambodia: A cognitive linguistics study
}

Muhammad Hafiz Kurniawan

Universitas Ahmad Dahlan, muhammad.kurniawan@enlitera.uad.ac.id

Follow this and additional works at: https://scholarhub.ui.ac.id/ajce

Part of the Social and Behavioral Sciences Commons

\section{Recommended Citation}

Kurniawan, Muhammad Hafiz (2018). Folk categorizations of western Champa in Cambodia: A cognitive linguistics study. ASEAN Journal of Community Engagement, 2(1).

Available at: https://doi.org/10.7454/ajce.v2i1.114

Creative Commons License

(c) (i) ()

This work is licensed under a Creative Commons Attribution-Share Alike 4.0 License.

This Research Article is brought to you for free and open access by the Universitas Indonesia at ASEAN Journal of Community Engagement. It has been accepted for inclusion in ASEAN Journal of Community Engagement. 


\title{
Folk categorizations of Western Champa in Cambodia a cognitive linguistics studies Muhammad Hafiz Kurniawan ${ }^{a^{*}}$ \\ aUniversitas Ahmad Dahlan, Indonesia \\ Received: April 27th 2018 || Revised: June 12th, 2018 || Accepted: July 2nd 2018
}

\begin{abstract}
Western Champa people are Cambodian citizens who moved to Cambodia due to pressure from the Vietnamese who began to build their strength and suppress them to the neighborhood country. Although their kingdom was originally in Vietnam and some of Champa people/Eastern Champa still live and thrive there, some of them were recorded to speak Austronesian language. Therefore, their language is slightly similar to Bahasa Indonesia and both languages are categorized as Malayo-Chamic. Two similarities of these languages that will be further discussed in this research are the words boh [boh] and talai [təlai] for buah [buwah] and tali [t $\Lambda \mathrm{li}]$ that means "fruit" and "rope" respectively. Although the sound appears to be the same in bahasa Indonesia, the categorizations using these words are uniquely different. The word chim [t $\left.\int \mathrm{Im}\right]$ is also the object of discussion because of its unique use for categorizing birds and insects. This research is aimed to explore the uniqueness of bahasa Cham in categorizing animal, vegetables and fruits, as well as objects and to discover the reason behind those categorizations, which are triggered mostly by metonymy. The method of this research is participant observation and interview while teaching Bahasa Indonesia for four months in Cambodia for BIPA program.
\end{abstract}

Keywords: folk categorizations, western Champa, cognitive linguistics, embodied metonymy.

\section{Introduction}

Cham Language is spoken not only in Vietnam but also in Cambodia. This language is divided into two dialects known as Eastern and Western Cham. The division between Eastern and Western Cham cannot be separated from the early history of the Kingdom of Champa that was found in the central of Vietnam (Musa and Shuhaimi, 2006, p. 32). This separation began when the Kingdom of Champa was pushed by the strength of the Viet at that time (Ibid p.34-36). The people of the kingdom began moving to the neighborhood kingdom and country, such as Cambodia, while some were still in south-east part of Vietnam where they now flourished (Musa, 2011, p. 25). Yet, the linguistics system of this indigenous language is still under the threat.

The Western and Eastern Cham people have started to forget their original writing system. This is because the language is used only in daily communication and when Cham people meet other Cham from other villages or countries (some Cham people start to be an immigrant to seek for refugee in the Pol Pot era 1975 - 1979 (Musa, 2011, p. 25)) to show their identity as Cham people. However, they use the national language, for instance Khmer, when communication with the Khmer even in the market for trading activity.

The Problem does not stop at that point. Western Cham began to change their writing system to Malay Arabic. This change is caused by the spread of the book of Islam in Cham and the scholars who got their degree from Arab country.

Yang saya faham tu,... Cham ini ada tulisannya dan tulisan tu dari Sanskrit lah.. dan orang yang dapat belajar dari negara-negara islam tu kalau belajar dengan tulisan arab lah. Mereka fikir kalau ajar anak-anak ni tulisan jawi memang lebih senang dari yang lain sebab mereka

\footnotetext{
*Correspondence Author: muhammad.kurniawan@enlitera.uad.ac.id
} 
nak ajar anak-anak ni agama Islam pakai huruf arab. Kalau tulisan Jawi di dalam education

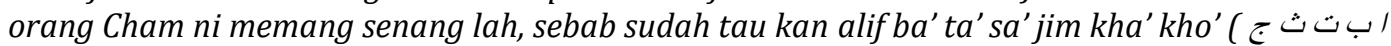
$\dot{\tau}$ ₹) tu kalau pakai huruf Jawi pun alif ba' ta' juga lah.(Safeat, personal communication, May $2,2017)$.

Translation:

What I understand is that, Cham indeed has its original writing system which is from (adaptation of) Sanskrit. And some scholars who got their degree in Islamic country learn (their subjects) by using Arabic writing system. (Therefore), they thought if (they) teach these children using Jawi is indeed easier because they are going to teach Islam using Arabic (too). If Jawi writing system (is used in) Cham education, (it) will be easier (for the method of learning Islam) because (these children) already knew alif $b a^{\prime}{ }^{\prime} a^{\prime}{ }^{\prime} a^{\prime} j i m k h a^{\prime} k h o^{\prime}$ ( ب ت $\dot{\tau}$ ¿ ج); (therefore), if (they) use Jawi alphabet as well, $a$ lif $b a^{\prime} t a^{\prime}$ (will be used) too.

The effort to preserve and reuse their original writing system seems difficult because it would put more pressure on the students who should study not only the Khmer writing system but also Malay Arabic and Arabic. Hence, this exploration has an aim to encourage the native Cham to learn their language and their original system. This paper tries to relate and compare Bahasa Indonesia and Bahasa Cham in the words both have in common. The comparison between those two languages are explained to give an additional prove that both languages have almost the same roots (Blust, 2013).

The close relation between Bahasa Indonesia and Cham language can be easily seen on their several basic words so that they are categorized as the Malayo-Chamic (Blust, 2013, p. 72). This does not mean that the use of those words is totally the same. For example, the word boh [boh] that means fruit or buah [buwah] in Bahasa Indonesia is used for different categorization. In Indonesia this word is used to classify fruit, the measurement (of stationary, cutlery, furniture and many else), verb that means 'to produce', idioms that are metonymically and metaphorically used. Conversely, in Cham language, this word is used to classify everything that are produced by creatures other than human. The production from creatures such as birds, plants, and even reptiles and bugs will be classified as boh [boh] and even for inanimate but has the spherical form. Other words that have similar way to pronounce but different ways to use and words that have different way to pronounce and different way to use compared to Bahasa Indonesia.

The other difference in use is also found in word talai [təlar]. The word talai in bahasa Cham is the same as the word tali [tali] in bahasa Indonesia. However, the use of these words from both languages is different, especially in categorizing some jewelry and accessories. The other word that has different use, pronunciation, and writing is Chim [t $\mathrm{f} \mathrm{Im}]$ that means 'bird' and 'insect'. Although the use of the word chim is quite different from burung and serangga, the comparison is still worth explaining. Furthermore, the word chim [t $\left.\int \mathrm{Im}\right]$ for bird has the same root as the Acehnese word cicem [cicém] (Thurgood, 1999, p. 314) because after their kingdom left to debris some of the Cham moved to other areas such as Kelantan, Johor, Malaka, Sumatera (including Aceh and Palembang (Musa, 2011, p. 26)) and Borneo (Ibid p. 24).

The categorization or classification has been made practically by the community before the rigid classification based on science was made. The categorization or classification made by community is called as folk taxonomies that give the alternative view of categorizing living things among the villagers that never studied the scientific taxonomy of western culture (Ungerer and Schmid, 2006, p. 67). These folk taxonomies not only give an insight to how the people classify the living things around them but also show how the 
people classify those living things based on their similarity on several aspects. The aspects taken from this might be triggered using metonymy. The reason behind choosing the words used to categorize the other living things based on metonymy will be explained in more detail in the discussion part.

The other aspects of choosing the names to some plants and animals in late 1800s can be based on economic emphasis such as for material culture, for food or medicine. On the other hand, the cognitivist view of classifying plants and animals is based on the conceptual connection between one another (Berlin, 1992, p. 4). Although there are some differences, those two views are greatly recognized in ethnobiological research (Ibid, p. 5). In terms of the cognitivist view, seven principles fall into ethnobiological categorization part and five others fall into ethnobiological nomenclature. One of those seven principles proposed by Berlin (principle 2) states that perceptual recognition of the people will take an important role in classifying plants and animals into some properties such as medicine, food, and ritual properties (Ibid, p. 21). While in principle 2 is included in the five principles of ethnobiological nomenclatures, the secondary name or plants or animals, in case of English, it will determine the groups of those living organisms (Ibid, p.28).

The case of English when the secondary name of plants and animals will determine the groups of those living organisms is rather different from most languages, even MalayoChamic language. In English, it is the secondary place or the end of the phrase that is called head of noun phrase (Van Gelderen, 2010, p. 33), which works as the generic name, and the word preceding the secondary name is the specific name. While, in Bahasa Melayu Champa the placing of the name of group or generic name is in the beginning of the phrase that is considered the generic name in this case (Chaer, 2008, p. 219). Therefore, this paper will emphasize on not only how the western Cham people categorize the living things such as animal chim [t $\mathrm{f} \mathrm{Im}]$ which means 'bird' and insect and product of plants and animal boh [boh] which means 'fruits', 'vegetables' and 'eggs' and even non-living being talai [t'laj] which means 'rope', but also why they use those words mentioned without leaving the brief analysis on the phrase structure.

Folk categorization or classification especially on plant classification was widely discussed by Berlin et al (1974) who conducted research on plant classification of Tzeltal people. This research explored every single part of plants such as roots, stems, bark, leaves, flowers and fruits (Ibid, p. 69-78) and even the shape and texture of the fruit and leaves that determine the way the people of Tzeltal classifying the plants and distinguishing them from one to another (Ibid, p. 85-94). Another researcher who considers the linguistic view is Morse (2015). In his research, Morse elaborated the folk taxonomy of Anishinaabemowin, a language spoken from Great Lakes region of the United States and Canada into Manitoba and Saskatechewan (Ibid, p. 12). In this research, Morse used endocentric and exocentric compounding in explaining the reason of naming the plants in Anishinaabemowin (Ibid, p. 18-26).

Meanwhile Ueda et al. (2016) conducted a research in the way of Javanese people giving the name to Mangifera spp. In this research, they try to find the reason behind the naming of $M$. odorata and M. feotida which are from the quality of the fruit only. Another research on folk taxonomy conducted by Agre et al. (2016) shows that the cassava in southern and central Benin is classified into some categories using the plants morphology (Ibid, p. 506). Rarely did the articles mentioned above elaborate the use of cognitive process in naming 
and categorizing creatures and things. Therefore, this paper will try to explain the reason behind naming of those things by using cognitive linguistic approach.

\subsection{Conceptual System and Cognitive Linguistics}

Taking one or more attributes from the prototype is one of the principles in cognitive psychology that become the foundation of cognitive linguistics (Evans and Green, 2006, p. 64). These principles including embodiment, environment, experience, perception, and categorization will be an influential principle (Ibid p. 64-68). The perception principle also has six principles in which one of those principles has greater extent in guiding the theory of this paper. The principle of similarity that emphasizes on visual elements such as shape, color, and even size (Ibid p. 66) influence human's cognition. The similarity of one thing to another so that it can be included as the same categorization is also closely related to the categorization principle. Furthermore, this similarity principle in perception was called metonymy because correlation is a fundamental conceptual system (Ibid p. 320).

Conceptual system is well known as the main foundation of cognitive linguistics in seeing the language phenomenon as a not-merely-structural phenomenon (Balkhimbekova et al., 2016, p. 3914). However, language is also used as the mental representation of people who speak it, and thus, it will not only reveal and mirror the conceptual system used in human mind but also the culture (Krawiec, 2012, p. 48). Hence the cognitive linguistics includes the study of culture in one of its branch (Baydak et.al, 2015) because culture and mind cannot be separated. Therefore, in the cognitive linguistics study the primary/core meaning of word with its pragmatic, social and cultural meaning will not be seen as different and distinct entities (Evans et al. 2007, p. 11).

This view of rejecting to differ the core meaning of word and the pragmatic, social and cultural meaning is included in the approach to cognitive semantics (Evans et al. 2007, p. 9-19). There are at least five approaches to semantics based on Evans, Bergen and Zinken (2007, p. 11) and one of those leads to how human recognizes something based on shape, taste, texture, color and even smell (Ibid p. 11). This approach is closely related to metonymy because all the knowledge human has is interconnected with the network within the object (Evans et al. 2007, p. 11)- or it can be called inner connection - and from one object to another that still has immediate connection or, in other words, the same domain (Littlemore, 2015, p. 10).

\subsection{Metonymy is one of ICM}

The immediate connection of one part of the object to represent the whole object is one of the principles in metonymy. ICMs, which stands for Idealized Cognitive Models, depicts the connection or interconnection between one thing to another with regard to not only human cognition and knowledge about particular thing but also cultural aspects (Radden and Kövecses, 2007, p. 336). Metonymy is rather different from metaphor in which the relation from one to another to make the abstract objects concrete by employing concrete objects as its source domain (Kovecses, 2010, p. 77). According to Radden and Kovecses in Littlemore (2015, p. 20) ICMs can be divided into two basic categories that each category will lead to several numbers of ICMs. These categories will be well-described in the figure 1. 


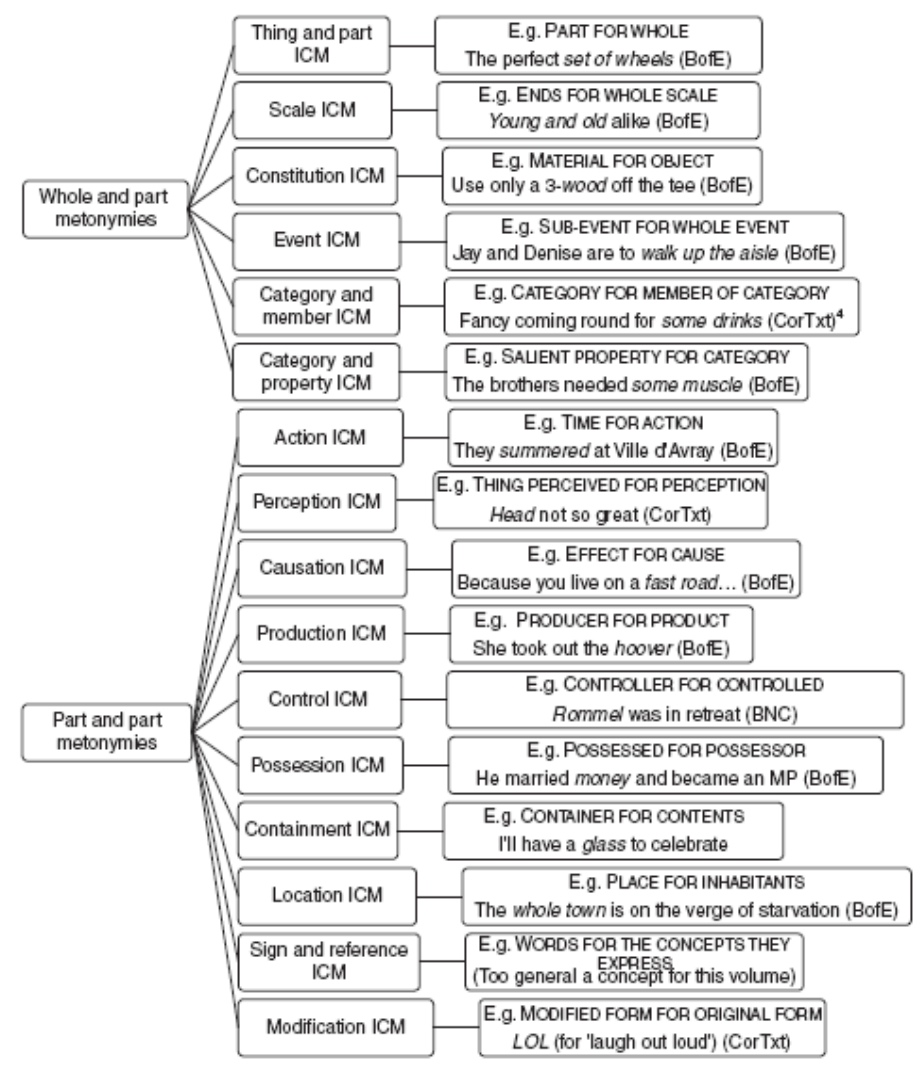

Fg. 1 Key of metonymy

Source: Littlemore (2015, p. 22).

\subsection{Metonymy and Categorization}

Metonymy and categorization have very close relation because in categorization or even in taxonomy the way to determine new species should be based on the similarity to the known and categorized species that have been classified hierarchically (Rouhan and Gaudeul, 2014, p. 3; Simpson, 1961, p. 19). The aspects such as morphology, anatomy, and genetics are taken into consideration to classify the creature, which is the plant in this case (Rouhan and Gaudeul, 2014, p. 2) and it is applied also to animal (Simpson, 1961, p. 2). The consideration on the similarity such as anatomy, morphology and genetics to classify the creatures and new creatures to be found, makes the taxonomy close to metonymy which in cognitive linguistics can be one of the reasons behind prototype (Kosecki, 2014, p. 512).

Prototype, one of the methods used in categorizing something based on the similarity among members in gradable manner (Riemer, 2010, p. 228), has been a trend in cognitive linguistics since the mid-1980's (Geeraerts, 2010, p. 183). However, this paper does not aim to show how the people of Western Cham categorizes the things and creatures around them by employing the prototype which is commonly arranged from the best example (in centre position) to the less good one (in outer position) in circular shape (Ibid p. 185). Instead of using circular shape to elaborate the data found in Western Cham people, this paper will use hierarchical system.

Hierarchical system in taxonomy is almost the same as categorization used in hyponymy (Riemer, 2010, p. 142) because categorization in hyponymy is rather similar to taxonomy (Ibid. p. 169). Folk taxonomy in this case has a significant difference to scientific taxonomy, 
in which scientific taxonomy is categorization based on a well-built method and analysis to categorize things and creatures while folk taxonomy is categorization that can be based on cultural and cognitive system. Therefore, folk taxonomy is commonly not in concordance with scientific taxonomy (Radden, 2008, p. 393). Even though there are some differences on determining the subcategory of things or creature between scientific and folk taxonomy, the hierarchical will be used to elaborate the data. The hierarchical system that will be used is not the same as what scientific taxonomy does in most research - the hierarchy that was arranged based on the Linnaean Hierarchy as applied in animal taxonomy (Simpson, 1961, p. 13). Instead, this hierarchy will be made based on the mental perception of the Western Cham people in categorizing thing (rope and spherical thing), creatures product (fruit, vegetables and eggs) and creatures (birds, insects, and bats).

\section{Methods}

The research on the folk categorization in Cham language was conducted by using participation method that is widely used in linguistic anthropology (Ahearn, 2017, p. 56). The data for this research were taken when the researcher was working as the Indonesia language instructor in one of Cham villages, Svai Khleang for four (4) months. The abundant of data from the native Cham was collected manually using paper and notes (Moleong, 2015, p. 131) to take the data in both words and sound of the words spoken by native Western Cham using IPA symbol. After that, the validity of the data was confirmed by asking the native Cham. These data were then classified and analyzed. To enrich the data taken from the first place, interviews using voice record and short message service via WhatsApp and Facebook Messenger were conducted.

\subsection{Study Area}

This research is conducted in two areas, Kampong Svai Khleang and Kampong Kbop in Krouch Chhmar district, Tbong Khmum province. These two villages (Kampong) are chosen because the researcher were sent to teach bahasa Indonesia primarily in Svai Khleang in Krouch Chmar district, Tbong Khmum province and three informants are from Kampong Kbop. This area is in $12^{\circ} 16^{\prime} 25.20^{\prime \prime} \mathrm{N}$ latitude and $105^{\circ} 38^{\prime} 20.99^{\prime \prime} \mathrm{E}$ longitude. This area can be reached in 4-5 hours by public transportation northeastward of Phnom Penh.

\subsection{The Steps in Collecting the Data}

The data collection stage is divided into three steps. However, before elaborating the steps in collecting the data, the informant's information needs to be shown first. The informants are four native Chams who never learned Malay but understand simple words for daily needs, and three native Chams who have learned Malay and can speak it very well, in addition to two native Chams who only know English and can speak it well. Hence, the total informants for this research are 9 informants. Four main informant helps collecting the data, while the rest help translating the Cham language into Malay and vice versa. The other five informants who know other languages besides their own language also help to confirm the data collected.

The first step is asking directly to the native Cham when the researcher found something unknown. The researcher started from the name of the things classified as boh [boh] because this classification is surprisingly used for anything spherical which is close to their everyday life, e.g. vegetables, fruits, eggs and other spherical things. Knowing the 
characteristics of the use of word boh [boh], the list of questions based on the prediction is made.

The categorization of bird and insect is found to be the same, which is called chim [t $\mathrm{fm}$ ], after the rain stops and countless flying termites began appearing. They also use this word to refer to bird and some flying animals. The list of birds and insects is also made based on the prediction of how they name flying animals. However, not all insects are called chim [t $\mathrm{f} \mathrm{Im}]$ because of their culture. This finding will be elaborated further in the result and discussion part. The last data to collect is the categorization of rope like things or talai [təlar]. This data appears while the teacher of the native Cham talked about the computer cable which they call as talai apui /təla apuij/. Afterwards, the investigation to collect other objects classified as talai /təlaI/ began after the teaching materials about clothes started. They classify necklace, belt, and bracelet as talai /təlaı/ as well.

The second step is taking note while remembering the sound of words referring to the thing which was explained. This step is done by asking the list of things according to each classification to the native Cham. The question is started by using their language hake ni? /hake? ni:?/, or simply put 'what is it?' to refer to several things written in the list. This way is used to avoid unnatural process of thinking because they must translate the other language first before they answer. After they answered the questions, all those data were written and transcribed using IPA (International Phonetics Alphabet).

To make the data more valid, the third step, which is called confirmation, is conducted. This third step is conducted to reconfirm the data collected through face-to-face interview and social media such as WhatsApp and Facebook Messenger. The social media mentioned have helped to store the voice record of the native Cham in adding some important data for the analysis part. The way of reconfirmation of the data collected in the previous steps is rather different because it is impossible to ask while pointing to the things referred by the words. Therefore, pictures of the things on the list were used by sending them through that social media and they were asked to record their voice while mentioning what those pictures were. After all data were collected, they were analyzed and elaborated using the theory explained in the previous pages.

\subsection{The Steps in Analyzing the Data}

In analyzing the data, firstly, the notes were collected and transcribed. Then, the sound transcription of the native Cham vocabularies is made using IPA symbol in order to make the non-native Cham capable to pronounce. The data is collected originally in form of sound rather that the written one. It means that the written form of those vocabularies came after the sound because the official Latinized Cham vocabularies is not made yet; therefore, the scholar from native Cham was asked to make the Latin form of those vocabularies. He was asked to do so because he is one of the scholars who know the original writing system of Cham. Secondly, to confirm that the transcriptions were correctly written, the sound records from the third step of collecting data were used. Afterwards, the words with their transcriptions were categorized based on the theory of metonymy and categorization using hierarchical system of hyponymy.

\section{Results and Discussion}

The data which were noted and recorded were classified into three general categories that will be elaborated in more detail in three parts as well. The classification is based on 
how the words observed are used to represent things and creatures in native Western Cham environment.

\subsection{Boh is for Fruits, Eggs, Vegetables (non-leaves), and Spherical Things}

The use of the word boh [boh] among Western Cham people is not limited to fruit since the word boh [boh] here is almost like Bahasa Indonesia in both the written form and pronunciation. In Aceh the word boh [boh] is also used to refer to fruits, eggs, and vegetables while in Cham it is used to refer to not only those but also spherical things. If it can be depicted, the word boh [boh] can be branched into two categories, namely creatures' natural product and spherical things. This separation between creatures' natural product and spherical things is not from the data because this separation is only in the theoretical perspective, not in the native Cham's perspective. In the native Western Cham's perspective, the word boh [boh] is simply for referring to fruits, eggs, tubers, non-leaves vegetables such as tomato, eggplant, onion, garlic and spherical things such as ball, knee bone, and stone. The theoretical perspective of the categorization using word boh [boh] will be elaborated through the figure below.

(?)*specific name is still unknown

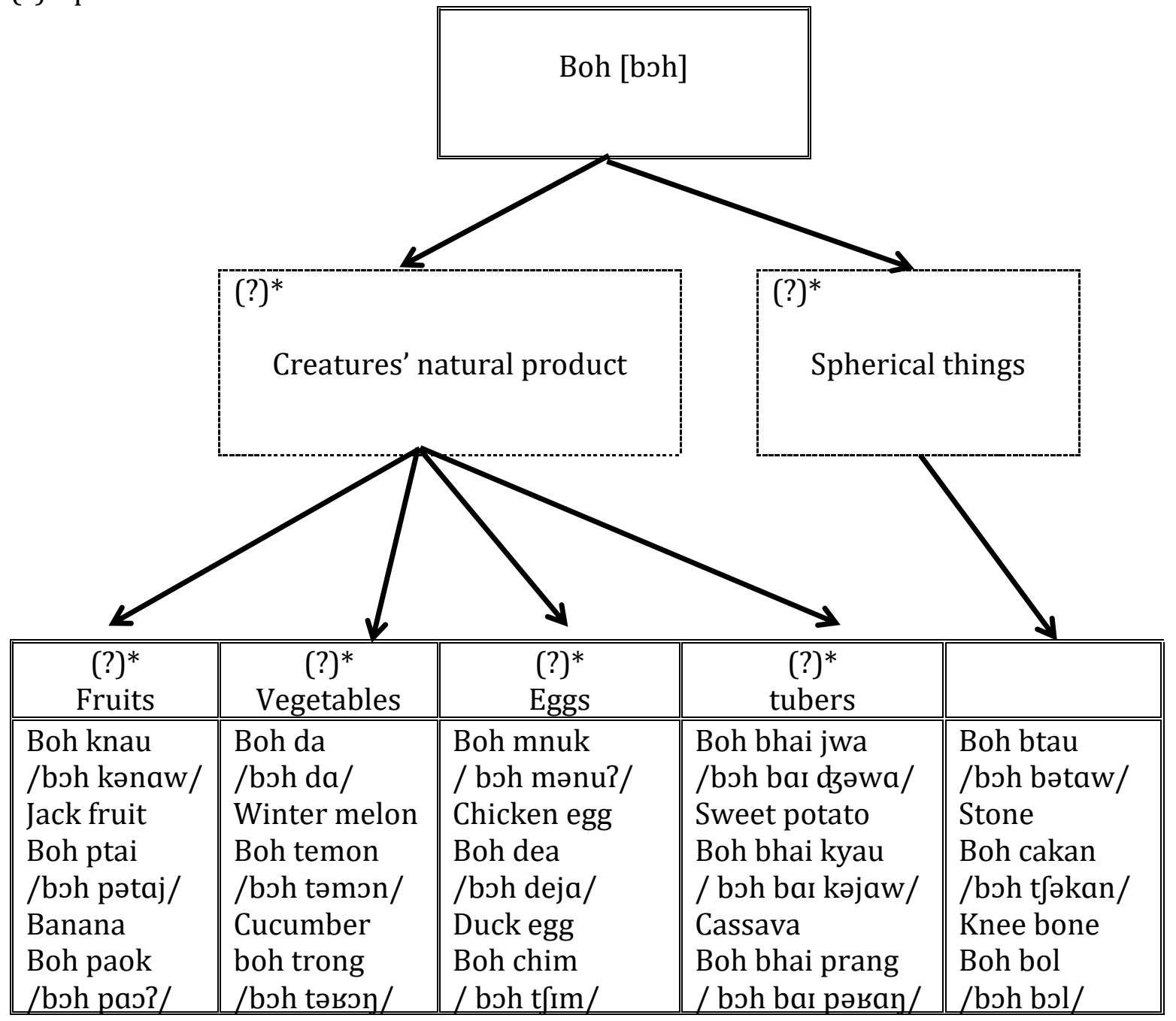




\begin{tabular}{|l|l|l|l|l||}
\hline Mango & Eggplant & $\begin{array}{l}\text { Bird/insects } \\
\text { egg }\end{array}$ & Potato & Ball \\
\hline
\end{tabular}

Fg. 2 The hierarchical system (hyponymy) of Boh in theoretical perspective Source: Adapted from Griffiths (2006, p. 52)

As mentioned before, figure 2 is a hierarchical system based on hyponymy but the native Western Cham might think this hierarchical system is inapplicable in that way above because it seems that the categorization for creatures' natural product was not identified/found yet during the four months I worked there. The possible reason why the word boh [boh] can be used for categorizing fruits, vegetables, eggs, tubers, and even spherical things might be explained by using semantic network. This semantic network will show the semantic features surrounding the word in the center that is symbolized with a node (De Deyne et al, 2016, p. 179). The semantic network will be shown below.

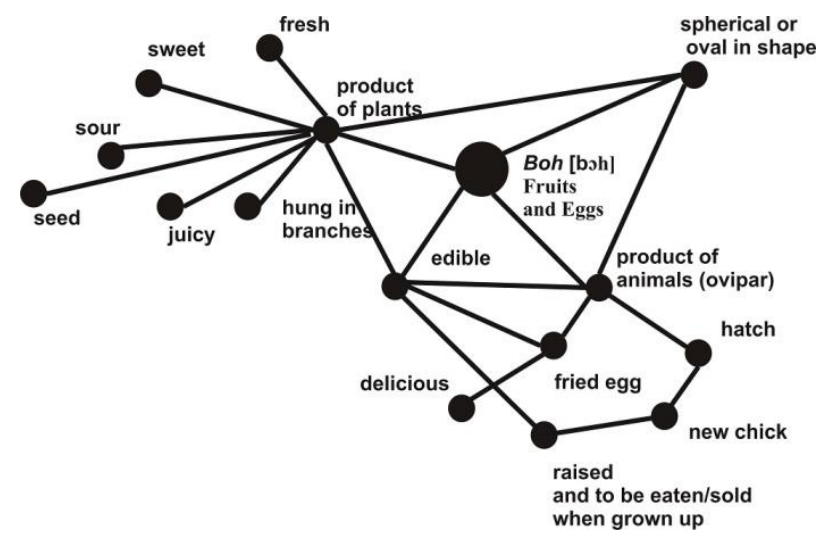

Fg. 3 Semantic network of lexicon boh

Source: Adapted from De Deyne et al, (2016, p. 180)

Figure 3 shows that the word boh [boh] that originally means fruits and eggs has several associated semantic features that make it possible to widen its use. As the data analyzed in figure 1, the word boh [boh] widen into tubers and even spherical things such as stones, knee bone, and ball. This widen sense is originally started from 'product of plants' node. This is called as the metonymic application of Category-and-Property ICM (Kovecses, 2010: 181). This is also the same as the widen sense for referring to spherical things such as stone, ball, and knee bone, in which in this case the word boh [boh] is the category which its main features in it are (1) product of plants, (2) edible, (3) product of animals (ovipar), and (4) spherical or oval.

Therefore, the word boh [boh] that refers to tuber takes the feature (1) product of plants, and (2) edible, and some of tubers in form of (4) spherical or oval shape. This is also applied for some vegetables that is taken from its root such as onion and garlic that are called boh son mereah /boh son mәвеjah/ and boh son ptih /boh son pətıh/. The word bhai [bai] that appears to refer to the tubers also should be recognized as the effort of native Cham to differentiate boh [boh] which is hung in the branches of tree and the boh [boh] which is produced in the root of tree. Meanwhile, the word boh [boh], which refers to stone, only takes (4) spherical or oval in shape feature as its main aspect of widening. The same feature is used as well in the word boh [boh] to refer to ball and knee bone. 
Additionally, the word after boh [boh] for referring to tubers is bhai [bar] that stands for tubers. This can be viewed as the way the native Western Cham tries to give detailed information about the thing which this word refers to. It can be seen from the structure of the phrase. The first word is the noun that functions as a head of phrase. This head is used to signify the generic names, the second noun is for the subordinate name, and the third or the last noun is for the specific name.

1. Boh bhai jwa /boh bai dzəwa/ ((HN + N1) + N2)

Fruit tubers Java

The tubers fruit from Java/sweet potato

2. Boh bhai prang /boh baı рәваy/ ((HN + N1) + N2)

Fruit tubers white

The tubers fruit with white color/potato

3. Boh bhai kyau /boh bai kəjaw/ ((HN + N1) + N2)

Fruit tubers wood

The tubers fruit like wood/cassava

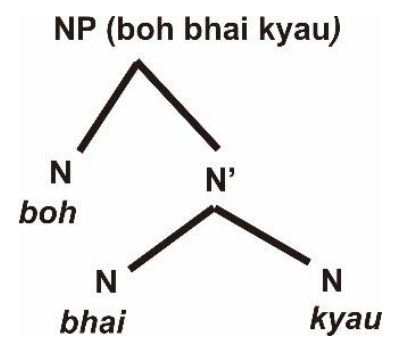

Fg. 4 The applicable structure for data 1-3

Source: Adapted from Van Gelderen,

(2010: p. 36)

The data 1 is the activation of Complex Event ICM because the informant from the native Cham said that Boh bhai jwa /boh bai dzəwa/ was predicted from Java Island. This information is gotten from one of the informants.

"Namanya boh bhai jwa karena kata ayah saya boh ini asalnya dari Jawa. Jadi namanya boh bhai jwa. (Hambli, personal information, June 22, 2017).

Translation:

This is called boh hai jwa because as what my father said, this boh came from Java. Therefore, this name of this boh is boh bhai jwa.

This is called Complex Event ICM because of the story behind the name of this tuber which is related to events in the past (Kovecses, 2010, p. 180). Meanwhile, data 2 and data 3 have different metonymy application from the data 1 . Data 2 has its name by two metonymies first is Complex Event ICM because the word prang [рәьау] stands for France people.

\footnotetext{
"Memang saya faham tu, prang [рәьар] tu memang dari French lah karena mereka nampak orang French ni putih kan" (Safeat, personal information, June 25, 2017).

Translation:

What I understand is (that the word) prang [рәьап] is indeed referred to French because they (native Cham) see that the French people is white (has white skin).
}

This word does not refer to all French people but the French who came to Cambodia during the French protectorate period 1863-1953 (Musa and Shuhaimi, 2006, p. 59-64). France (country) for the people at that time is called Location ICM (Radden and Kovecses, 2007, p. 348) because the country stands for the people from France. After that the next metonymy applies to this word prang [рәвап] that stands for white because of the French's skin colour. This is again the activation of Category and Property ICM when the DEFINING 
PROPERTY for CATEGORY (Ibid, p. 181). Figure 4 below can provide the process of changing metonymy in the native Western Cham toward the word prang [рәвар].

Furthermore, the phrase Boh bhai kyau /boh bai kəjaw/ that stands for cassava activates the Category and Property ICM, one property for the category (Kovecses, 2010: 181). The reason is that the word kyau or wood appears to make the characteristics of this kind of tuber clear. The features of this tuber i.e. (1) wood-like tuber, (2) edible, (3) produced in the roots of the tree, (4) tasteless are represented by one feature that is likely to make it different from another tuber.

\subsection{Chim for Birds and Insects (non-edible and commonly found to fly)}

The word chim [t $\mathrm{frm}]$ which refers to two creatures i.e. birds and insects has more simple broadening process than the word boh [boh] above. However, before exploring the reason behind its broadening process, it is better to reveal the possibility of the original meaning of the word chim [t $\mathrm{f} \mathrm{Im}$ ]. This word basically means 'bird' (Thurgood, 1999, p. 314). It can be analyzed that the word is formed from onomatopoeia because this word is closely related to the sound of bird that falls into the onomatopoeia. The word that is predicted to be derived from onomatopoeia is not only chim $[\mathrm{t} f \mathrm{Im}]$ but also for 'cat' megiu [məyiju], 'raven' chim ark / $\mathrm{t} f \mathrm{Im} æ: ? /$, and 'cow' lemou /ləmow/. This onomatopoeia is called iconicity because of nature mimicking process.

The word chim [t $\mathrm{f} \mathrm{Im}]$ which is used for referring to bird and insect nowadays is rather different from what was described by Thurgood in his book. The book which was published in 1990 showed that fly, bug, and insect are ruai [ruai] (Ibid p. 330). It is predicted to change time by time into chim [ $\mathrm{t} f \mathrm{Im}]$. It can be said that the word chim [t $\mathrm{t} \mathrm{Im}]$ which refers to bird broadens into symbol to refer to insect. The figure below will elaborate the hierarchy for the word chim $\left[\mathrm{t} \int \mathrm{Im}\right]$ in the theoretical perspective.

(?)*specific name is still unknown

\begin{tabular}{|c|c|c|c|}
\hline & \multicolumn{2}{|c|}{$\begin{array}{l}\text { Chim } \\
{\left[\mathrm{t} \int \mathrm{Im}\right]}\end{array}$} & \\
\hline $\begin{array}{c}\text { chim }\left[\mathrm{t} \int \mathrm{Im}\right] \\
\text { Birds }\end{array}$ & \multicolumn{2}{|c|}{$\begin{array}{l}(2017,(?))^{*}(1999, \text { ruai [ruai]) } \\
\text { Insect } \\
\text { (Non-edible) (Commonly found to fly) }\end{array}$} & $\begin{array}{l}\text { Chim tou } \\
/ \mathrm{t} \int \mathrm{Im} \text { touw/ } \\
\text { Bats }\end{array}$ \\
\hline$\downarrow$ & & & \\
\hline $\begin{array}{l}\text { Chim titui } \\
\text { /t } \int \mathrm{Im} \text { tituj/ } \\
\text { Owl } \\
\text { Chim ark } \\
\text { /t } \int \mathrm{Im} æ: \mathrm{l} / \\
\text { Raven } \\
\text { Chim chraw } \\
\text { /t } \text { Im t } \mathrm{t} \text { əraw/ } \\
\text { Pigeon } \\
\text { Chim ngie } \\
\text { /t } \text { Im niju/ }\end{array}$ & $\begin{array}{l}\text { Chim eh lemou } \\
/ \mathrm{t} \int \mathrm{Im} \\
\text { ch ləmow/ } \\
\text { Dung beetle } \\
\text { Chim tet } \\
\text { /t } \int \mathrm{Im} \text { tət/ } \\
\text { Butterfly } \\
\text { Chim ea jan } \\
\text { / } \mathrm{t} \text { Im eja dzan/ } \\
\text { Flying termites } \\
\text { Chim geng }\end{array}$ & $\begin{array}{l}\text { EDIBLE INSECT } \\
\text { COMMONLY FOUND } \\
\text { TO FLY } \\
\text { Nii } \\
\text { [ni:] } \\
\text { Bee } \\
\text { Cket } \\
\text { [t } \text { fokət] } \\
\text { Cricket } \\
\text { Khtook } \\
\text { [kətว:?] }\end{array}$ & \\
\hline
\end{tabular}


Muhammad Hafiz Kurniawan | ASEAN Journal of Community Engagement | Volume 2, Number 1, 2018

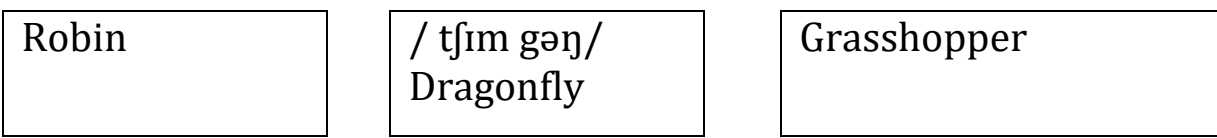

Fg.5 The hierarchical system (hyponymy) of word chim [t $\mathrm{f} \mathrm{Im}]$ from theoretical perspective Source: Adapted from Griffiths (2006, p. 52)

Figure 5 provides a view how native Western Cham categorizes the word chim [t $\left.\int \mathrm{Im}\right]$ for bird and insect when I visited Svai Khleang village, one of Cham villages in Cambodia, a year ago. The word chim [t $\left.\int \mathrm{Im}\right]$ is used to refer to not only bird and insect, especially the non-edible and commonly-found-to-fly one. However, the edible insect such as bee, the baby bee especially, grasshoppers, and crickets is not called chim [t $\mathrm{fm}$ ]. The properties or features which are taken from chim [t $\mathrm{f} \mathrm{Im}]$ which means bird to refer to insect include (1) has wing, and (2) the ability to fly, and probably (3) producing eggs feature too because bird has at least 8 features corresponding to it, such as (1) has wing, (2) the ability to fly, (3) has beak, (4) has two feet, (5) has claws, (6) producing eggs, (7) has feather, and (8) has tail.

Moreover, the uniqueness in naming the bird chim [t $\left.\int \mathrm{Im}\right]$ to refer to insect should also be explored here. First, the name of bird was derived from onomatopoeia, raven chim ark / $\mathrm{t}$ Im $\varepsilon: ? /$ and second is the name of insects which are derived from the time they appear such as after raining (chim ea jan / $\mathrm{t} \int \mathrm{Im}$ eja dzan/) the things that is involved in their action (chim eh lemou / $\mathrm{t}$ Im $\mathrm{eh}$ ləmow/) and their similar appearance to a part of a building, pillars (chim geng / $\mathrm{t} \int \mathrm{Im}$ gəy/). Here is the short analysis of their meaning.

4. chim ea jan /t $\int \mathrm{Im}$ eja dzan/ $(\mathrm{HN}+(\mathrm{N} 1+\mathrm{N} 2))$

Insect water rain

The insect which appears after rainfall/flying termites

5. chim eh lemou / $\mathrm{t}$ Im $\varepsilon$ h ləmow $/(\mathrm{HN}+(\mathrm{N} 1+\mathrm{N} 2))$

Insect poop cow

The insect which likes to collect cow's poop/Dung beetle

6. chim geng / $\mathrm{t}$ Im gəy/ (HN + N1)

The insect which is like pillar/Dragon fly

Pillar-like insect

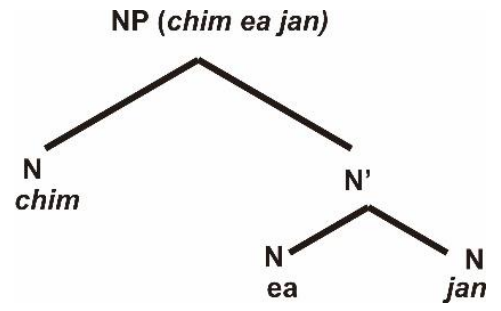

Fg. 6 The applicable structure for 4 and 5

Source: Adapted from Van Gelderen, (2010: p. 36)

The chim [ $\left.\mathrm{t} \int \mathrm{Im}\right]$ in number 4 is the activation of Complex Event ICM because this insect, the flying termites, come after the raining stops. This is included in SUCCESSIVE SUBEVENTS FOR COMPLEX EVENTS that happens in the end of the raining events (Kovecses, 2010, p. 180). This is like data 5. The Action ICM because the specific name represented by the phrase eh lemou / $\mathrm{ch}$ ləmow/ is the object involved in the action of this beetle (Ibid, p. 181). However, data 6 has different mental process from other data explained before. This data includes the activation of metaphor because this data shows there are two different domains involved. The first domain is the chim [ $\mathrm{t}$ [m] that means insect and the second domain is the pillar, a part of building. 


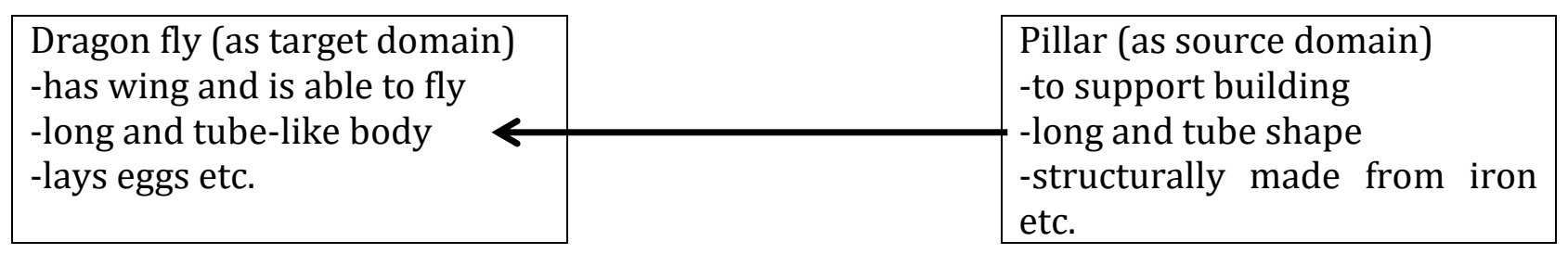

Fg.7 Conceptual metaphor of DRAGONFLY (target domain) is PILLAR (source domain) Source: Adapted from Evans and Green (2006, p. 308)

\subsection{Talai for All Rope-like Things}

The last discussion is about the word talai [təlar]. This word refers not only to rope that is used for tightening the farm animal such as cow, horse, and goat, but also to accessories such as necklace, bracelet, belt and even electric cable. The broadening process of this word can be traced to mostly metonymy and metaphor especially in the specific names. Here is the hierarchical system (hyponymy-based view).

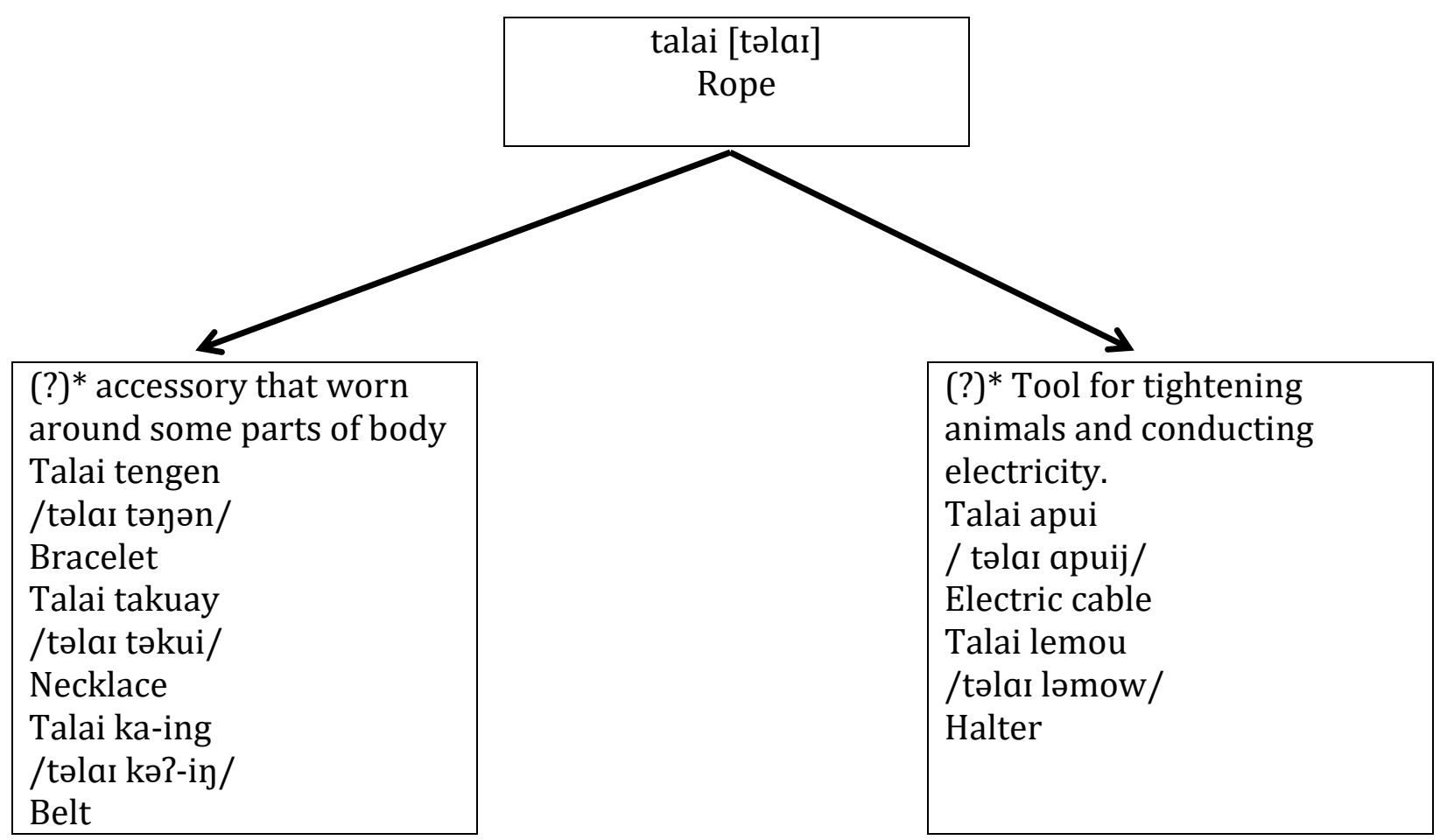

Fg. 8 The hierarchical system of word talai [təlar] means rope in theoretical (hyponymy) view Source: Adapted from Griffiths (2006, p. 52)

The use of the word talai [təlaI] to refer to such accessory as bracelet, necklace, and belt cannot be separated from the features that the word talai [təlar] has. The possible features that it has in native Western Cham are (1) long or medium in length (2) enough to be used around something, (3) thin or thick in form and (4) flexible. Therefore, the use of this word to refer to bracelet, necklace, and belt at least takes features (2), (3), and (4). However, in some cases, bracelet can be solid in form or inflexible so feature number (4) might be 
excluded. This is the same application with this word's use when referring to halter. However, the use of this word for electric cable only takes features (1), (3) and (4).

Moreover, the structure of the member of the subordinate level as in figure 9 is formed by two nouns. The first noun is the head of the phrase which functions as the generic level. This head gives the sign of superordinate level and the second noun is to signify that this talai [təlaI] is used in a place and for a purpose. It can be seen in the explanation below.

7. Talai tengen/təlai təџən/ $(\mathrm{HN}+\mathrm{N} 1)$

Rope hand

Rope that is worn in hand/bracelet

8. Talai takuay /təlai təkui/(HN + N1)

Rope neck

Rope that is worn in neck/necklace

9. Talai ka-ing/təlaı kə?-in/(HN + N1)

Rope waist

Rope that is worn in waist/belt

10. Talai apui /təla apuij/(HN + N1)

Rope fire/electricity

Rope that is used to conduct electricity/electric cable

11. Talai lemou/təla ləmow/(HN + N1)

Rope cow

Rope that is used to control the cow/halter

The metonymy from data 7, 8, 9, 10, and 11 is the Category and Property ICM because each of the data shows one of the properties (Radden and Kovecses, 2007, p. 344) such as hand in data 7, neck in data 8 , and waist in data 9. All of those data show the place in which this rope is worn, while the rest, data 10 and 11, show the purpose of the use of rope. However, the metaphor is applied in data 10 especially in the second noun. The word apui [apuij] that means fire are metaphorically related to electricity. This involves two frame domains: fire and electricity, where electricity is the target domain and fire is the source domain because fire is more concrete than electricity. Each domain has features which are shared from source domain to target domain.

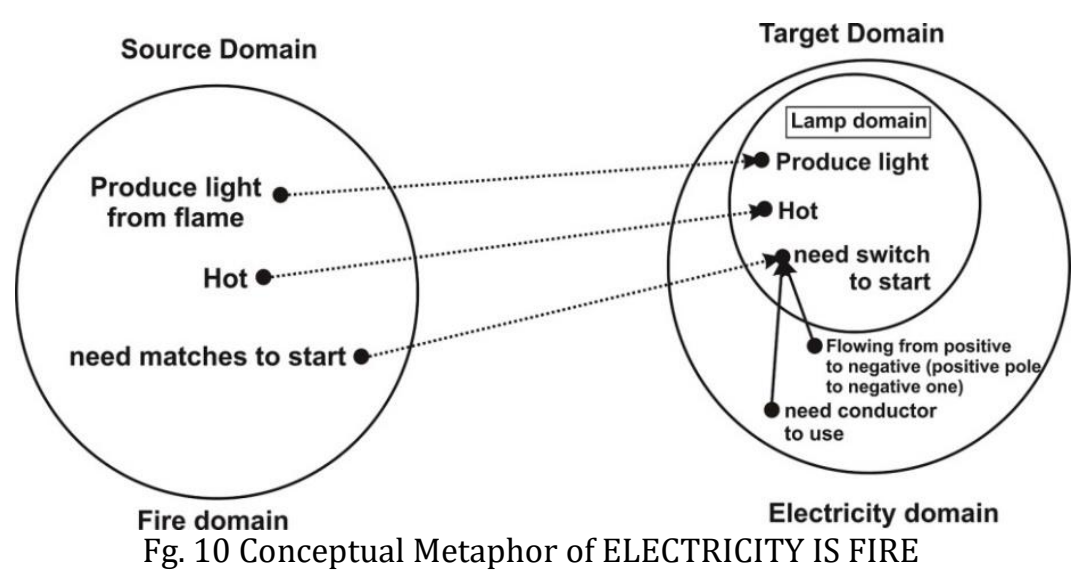

Source: Adapted from Kövecses, (2010, p. 281) and Evans and Green (2006, p. 52) for metaphor and (p. 313) for metonymy 
Figure 7 shows the relation between fire and electricity in mind and the features inside the circle is the characteristics of each domain. The electricity domain is not directly correlated to fire, but it is connected through the lamp that has similar function and characteristics to fire. Therefore, the connection between FIRE and ELECTRICITY is metonymy at first between ELECTRICITY and LAMP and then metaphor at second between the LAMP and FIRE. The Metaphor is applied because there are three similar features between FIRE and LAMP i.e. (1) produce light, (2) hot, (3) need something to start the light. Then, the relation between LAMP and ELECTRICITY is called Production ICM metonymy because the thing produced, light, stands for the producer, the electricity (Radden and Kovecses, 2007, p. 347).

Moreover, the metaphor process from FIRE to LAMP am an artifact of a period when electricity is not found or not used yet by the native Western Cham. As asserted by one of the native Western Cham, the electricity started to enlighten the village two years ago counted from 2017(Saefat, personal information, June 25, 2017). Therefore, the word apui [apuij] is still used to refer to the light to enlighten a room but not the natural light from the sun and the moon that is called tanrak. Thus, moonlight and sunlight are tanrak ea blan /tanrak eja bəlan/ and tanrak ea hrai /tanrak eja sai/ respectively (Faisal Romly, personal information, February 14, 2018).

The use of ea [eja] to replace yang [jan] is one of the native Western Cham rejection of the Buddhism symbol which believes in gods. The meaning of yang [jan] is god, so the sun and the moon in Cham people's old believes are considered gods. The replacement from yang to ea is not because of metonymy or metaphor because the word ea originally means 'water' so there is no logical correlation between 'gods' and 'water'. This replacement is commonly called rhyme in stylistics because it has the same sound or phonemic equality (Wales, 2011, p. 371). The similarity between ea [eja] and yang [jan] is the semivowel [j]. This semivowel in the word yang must start with the high vowel [i] first before this semivowel is pronounced (Ladefoged and Johnson, 2011, p. 233) while the word ea [eja] is considered a diphthong and it is naturally added with the semivowels [j] (Ibid, p. 93).

\section{Conclusion}

The categorization of the native Western Cham on boh [boh], chim [t $\mathrm{fm}$ ] and talai [təlai] are triggered initially by metonymy and the application of metaphor and then metonymy occurs in the word after the word talai [təlai], apuy [apuij]. Each of the word boh [boh], chim [t $\left.\int \mathrm{Im}\right]$ and talai [təlar] is used to categorize creatures and things mostly by applying Category and Property ICM and the specific name of these words, indeed, lead to other complexity in metonymy application such as Complex-Event ICM for the word chim ea jan, Complex-Event, Location, and Category and Property ICM for the word prang dan means 'white' which originally derived from word France.

It can be concluded that basically all those categorizations are the result of metonymy application, Category and Property ICM to be more precise because this kind of metonymy will provide the way in categorizing by taking one important property or feature so that it can be easily noted and understood. By understanding the way Cham people classify living things and things based on similar shape and features, it is easier to learn their language so that the bond between the volunteers and researchers can be stronger and the boundaries 
can be thinner. The exploration of Cham language also needs to be made to raise their confidence in preserving their language.

\section{Acknowledgment}

This research received funding from PPSDK (Pusat Pengembangan Strategi Diplomasi dan Kebahasaan), Badan Pengembangan dan Pembinaan Bahasa under the Ministry of Education and Culture; and supported by Universitas Ahmad Dahlan, and Yayasan Musa Asiah Foundation in the BIPA (Bahasa Indonesia untuk Penutur Asing) program for four months in Cambodia.

\section{References}

Agre, A P., Gueye, B., Adjatin, A., Dansi, M., Bathacharjee, R., Rabbi, I. Y., \& Gedil, M. (2016). Folk taxonomy and traditional management of cassava (Manihot esculenta Crantz) diversity in southern and central Benin. International Journal of Innovation and Scientific Research, 20 (2), 500-515.

Ahearn, L. M. (2017). Living language: An introduction to linguistic anthropology. West Sussex: Willey Blackwell.

Balkhimbekova, P. Z., Kossymova, G. S., \& Markova, E. M. (2016). Semantic and cognitive specificity of english verbs to destroy, to demolish, to ruin and their equivalents in russian translation. The Social Sciences 11 (16), 3914-3919.

Baydak, A. V., Scharioth, C., \& Ilyashenko, A. A. (2015, June 09-11). Interaction of language and culture in the process of international education. Paper presented at the International Conference for International Education and Cross-cultural Communication, Tomsk Polytechnic University, Tomsk, Russia.

Berlin, B., Breedlove, D. E., \& Raven, P. H. (1974). Principles of Tzeltal plant classification: An introduction to the botanical ethnography of a Mayan-speaking people of highland chiapas. New York: Academic Press.

Berlin, B. (1992). Ethnobiological classification: Principles of categorization of plants and animals in traditional societies. Oxford: Princeton University Press.

Blust, R. (2013). The austronesian languages. Canberra: Asia Pacific Linguistics.

Chaer, A. (2008). Morfologi bahasa indonesia. Jakarta: Rineka Cipta.

De Deyne, S., Kennet, Y. N., Anaki, D., Faust, M., \& Navarro, D. J. (2016). Large scale network representations of semantics in the mental lexicon. In M. N. Jones (Ed.) Cognitive Science: From Method to Insights (pp. 174-202). Psychology Press.

Evans, V., Bergen, B. K., \& Zinken, J. (2007). The cognitive linguistics enterprise: An overview. In V. Evans \& J. Zinken (Eds). The Cognitive Linguistics Reader (pp. 2-36). London: Equinox.

Evans, V., \& Green, M. (2006). Cognitive linguistics: An introduction. Edinburgh: Edinburg University Press.

Geeraerts, D. (2010). Theories of lexical semantics. New York: Oxford University Press.

Griffith, P. (2006). An introduction English semantics and pragmatics. Great Britain: Edinburgh University Press.

Kovecses, Z. (2010). Metaphor: A practical introduction. New York: University of Oxford.

Kosecki, K. (2014). On prototype-related metonymic models in signed languages. Kwartalnik Neofilologiczny, 61 (3), 511-527. 
Krawiec, M. (2012). Language as a mirror of cultural stereotypes-An ethnolinguistic perspective. Acta Neophilologica 14 (2), 47-88.

Ladefoged, P., \& Johnson, K. (2011). A course in phonetics. Canada: Wadsworth Cengage Learning.

Littlemore, J. (2015). Metonymy: Hidden shortcuts in language, thought, and communication. Cambridge: Cambridge University Press.

Moleong, L. J. (2015). Metodologi penelitian kualittatif. Bandung: PT. Remaja Rosda Karya.

Morse, S. J. G. (2015). Folk taxonomy in Anishinaabemowin: A linguistic approach (thesis). Retrieved June 11, 2018, from https://search.proquest.com/openview/16c9bd7fac46d48d314a7572994ff981/1? pq-origsite $=$ gscholar $\& \mathrm{cbl}=18750 \&$ diss $=\mathrm{y}$

Musa, M. Z. (2011). Diaspora Melayu Cam. Kuala Lumpur: Persatuan Sejarah Malaysia

Musa, M. Z., \& Shuhaimi, N. H. (2006). The cham community through the ages. Malaysia: Ikatan Ahli-Ahli Arkeologi Malaysia.

Radden, G., \& Kövecses, Z. (2007). Towards a theory of metonymy. In V. Evans, B. K. Bergen, \& J. Zinken (Eds.), The Cognitive Linguistics Reader (pp. 335-359). London: Equinox.

Radden, G. (2008). The cognitive approach to language. In J. Andor, B. Hollósy, T. Laczkó, \& P. Pelyvás (Eds.) When Grammar Minds Language and Literature: Festschrift for Prof. Béla Korponay on the Occasion of his 80th Birthday, 387-412. Debrecen: Institute of English and American Studies.

Riemer, N. (2010). Introducing semantics. New York: Cambridge University Press.

Rouhan, G., \& Gaudeul, M. (2014). Plant taxonomy: A historical perspective, current challenge, and perspective. In P. Basse (Ed.) Molecular plant taxonomy: Methods and protocols (pp. 1-37). New York: Humana Press.

Simpson, G. G. (1961). Principle of animal taxonomy. New York: Columbia University Press.

Thurgood, G. (1999). From ancient Cham to modern dialects: Two thousand years of language contact and change. Honolulu: University of Hawai'i Press.

Ueda, Y., Ito, S., \& Higuchi, H. (2016). Folk taxonomy and uses of non-Indica Mangoes (Mangifera spp.) in Java island. Tropical Agriculture and Development, 60(3), 200203.

Ungerer, F \& Schmid, H. J. (2006). An introduction to cognitive linguistics. Malaysia: Pearson Longman.

Van Gelderen, E. (2010). An introduction to the grammar of English. Philadelphia: John Benjamins Publishing Company.

Wales, K. (2011). A dictionary of stylistics. New York: Routledge. 